\title{
OPHTHALMOLOGY IN THE EUROPEAN UNION AT THE BEGINNING OF THE 21ST GENTURY AND ITS OPENING TOWARDS EASTERN EUROPE
}

\author{
Rolf Grewe
}

\begin{abstract}
SUMMARY - The present situation of the European Union in University clinics, hospitals and practises is described. The expected changes which will result from the entry of central European countries into the European Union are pointed out.
\end{abstract}

If we analyze ophthalmology in Europe on the threshold of the 3rd millennium we will notice that it is mainly in the 2nd half of this century that epochal developments in the diagnostic and therapy fields have taken place.

Today the half-life value of ophthalmologic knowledge is less than 5 years compared with 30 years in 1960.

The revolution through electronic media and robots has arrived.

There is a long-term, strategic dilemma in medicine affecting each country of the European Union, irrespective of which political party is in power; the dilemma would even persist if all doctors and patients were angels and if the industry was a branch operation of the salvation army.

This dilemma consists in the fact that modern medicine is increasingly becoming a victim of its own success. If today's medicine was not as good as it actually is, we would be spared many unpleasant decisions. In all EU countries, the current health care system implies a patient - orientated health promotion with a zero-cost-mentality and no personal responsibility of patients.

\section{Health care system}

Most health care systems in the EU do not as yet deserve a characterization as a system, since they lack a systematic coherence.

Correspondence to: Rolf Grewe MD, Frauenburgstr. 12, D-48155 Muenster Germany
The multitude of self-contained, sectorial sub-systems such as the out-patient and the in-patient departments, the rehabilitation and nursing care sector should be taken as the basis for the development of an integrated system which can be financed and be introduced with its elemental features in all EU-countries.

The main problem for member states is the financial issue, since most statutory health insurance funds are paid entirely or partially by the taxpayer.

This also means that the state as the financial backer and legislator exert an influence on the medical care provided to its citizens. But in order to shift costs and risks, states increasingly tend to withdraw from the health care system on an EU-wide level.

The traditional financing through taxes and/or membership fees is being converted step by step to a financing through health insurance contributions exclusively. The result is a monistic dependency on health insurance funds because it is always the financial backer who will exert this influence on the health care system. The statutory health insurance funds are currently preparing for a harmonizing process. They want to become a "player» instead of a «payer» and establish a global financing control. Their goal is to achieve extensive price stability through a more efficient use of insurance contributions.

First of all, this process will impair the situation of the medical professions. Additional payment regulations already existing today should be harmonized EU-wide.

This form of a health care system should be the goal the future EU members such as Croatia, Slovenia, Hun- 
gary, Poland, the Czech Republic and Estonia in anticipation of an all-European health care system.

As far as I know, Poland has already followed that development to a large extent.

First regional trials concerning the monistic integration can already be seen in some member states. New forms of out-patient care have developed such as patient networks for the dovetailing of the services of family doctors and specialists including high-performance medicine of clinics and hospitals, with specialists withdrawing more and more from their own surgeries and instead being integrated in the work of hospitals in the form of out-patient clinics. Such a system has already become a part of standard medical care in the Netherlands, for example.

It is not the quantity of services, but the quality of treatment provided in certain time units and the associated costs that will be decisive for the future success of the organizational innovation in the out-patient and in-patient fields. In consideration of this fact the professional association German ophthalmologists (BVA) have established «Practical action guidelines for diagnosis and therapy in ophthalmology following the «Preferred Practice Patterns» of the American Academy of Ophthalmology.

In the case of the networked surgeries, the use of the health economical evaluation is of great interest to all those involved. All doctors participating in the network could continuously document the quality and economic efficiency and could therefore start out from a basis for fairer remuneration negotiations with those bearing the costs. Similar is the argumentation need in the case of hospitals.

Health insurance funds, for their part, would be able to recognize what the insurer money is spent on. In this way, arguments for a competition among those bearing the costs would arise if the unified insurers exiting in the EU date were multiform in the sense of the German insurance system.

How would physician as a service provider benefit from the establishment of an integrated health care system?

Enticing as the role of the health economy for the system management may be, the doctor becomes a medicine manager. In the case of those doctors who view their work primarily as a means of moneymaking rather than a service provided to the patient, this is certainly true already today.

Some doctors turn away from the fundamental values of medical ethics towards globalized capitalism.

This capitalism is immoral, i.e. it remains neutral with respect to all moral issues. Questions of the human worth, metaphysical questions after all, will only be discussed in order to solve problems to achieve economic success.

They develop the wonderful ability to produce something like a manic obsession; at the same time, they for- get that the medical capitalism can avoid its self-destruction only if it recollects its legitimate propelling powers.

Medical treatment requires primarily affection in order to gain the patient's confidence. Appliances and high-tech medicine necessarily contribute to the doctor/patient relation, but they cannot replace it. Personal affection cannot be measured in the framework of the health economical evaluation. The discussion with our patients is our most important resource and we have to make the most out of it.

This, ladies and gentlemen, is the moral / ethical starting point which we are facing at the end of the 2 nd millennium; the decision is up to each of us.

\section{University Clinics}

The structure of university clinics must be revised and updated according to today's requirements. The activities of doctors working in such hospitals are not limited to medical care but include research and teaching. Research and teaching are more and more integrated at universities and colleges while medical tasks in the clinics and outpatient clinics are allocated to a special financing company which has to finance itself on its own out of fees.

In the future, part of the physicians up to the level or senior physicians should dedicate their work to the maximum medical care exclusively, without being obliged to participate in research activities.

If we as Europeans do not wish to be a consuming developing country compared to America, the cross-border focussing of all research powers is impressive. In this context Eastern Europe will make an important innovative contribution as it did in the past.

\section{Team doctor model}

The team doctor model should be introduced in clinics in order to improve the efficiency of interdisciplinary procedures through the simultaneous involvement of qualified physicians from different disciplines.

\section{Further vocational training of ophthalmologists}

Ophthalmologists are continuously required to broaden their specialist knowledge. In the European Union, the Board of Ophthalmology founded the CME «CONTINUOUS MEDICAL EDUCATION». The ophthalmology section of the «Union Europeene' des Medecins Specialistes» (UEMS) is currently preparing a certification program for an EU-wide ophthalmologic training, the most important approaches of which follow the American training regulations. 
In coordination with other EU countries models are being discussed which would limit the right to bear the title of a specialist physician to five years: «non-permanent specialist».

By successfully attending further vocational training courses the title can be regained for another five years.

\section{Networked thinking}

Apart from specialized capability, patient leading and motivation, the importance of being able to think in terms of a network is steadily increasing. Knowledge is a resource that will not use up when being used but it will increase instead. The combined knowledge of all physicians working in a clinic or a joint practice will increase the chances to make the right diagnosis and to apply the appropriate therapy.

The use of technical networks such as Internet and Intranet are prerequisites for a successful knowledge management.

This means that physicians have to change completely their way of working and thinking in order to foster an integration that is indispensable for an ideal clinic and practice management in the future.

\section{Prospects for the European Health Care System}

In the EU, EU law in some sectors has already replaced more than $70 \%$ of national law. This trend is increasingly becoming clearer also in the health care system due to the Maastricht and Amsterdam agreements. It is true that the different health care systems, mostly financed through tax revenues, with unified national health insurers cannot be harmonized in the short term.

But the force of a Europe that is growing together has already now led to the establishment of valid regulations concerning the fight against addiction and diseases and the overall provision of high-performance medicine to the population as well as a uniform quality management.

What will the coming century have in store for European ophthalmology? Those who are expecting serious answers must be content with suppositions. It is not a question of predictions but of contours and of the direction and the pace of development.

With the opening of the EU towards Eastern Europe and the advance of global thinking, the way medicine sees itself moves from a national and regional strategy towards global and cross-culture research and therapy application.

The strongest impulses of the EU opening towards Eastern Europe will stem from intellectual progress, from the knowledge and the ability to convert them into an innovative medicine. The intellectual resources will optimize this development as they did in the past.

It is mainly these countries that will enhance research on the basis of the existing level of medicine.

In the new millennium, the infinitely expandable knowledge through global research and putting that knowledge into practice will produce an undreamt-of success. Computers and the discovery of cyberspace will initiate a gigantic learning process. The immaterial part, i.e. what people think, research and invent will dominate the material and technical achievements. We cannot leave this development to the USA.

\section{Conclusion}

The first millennium started with Ptolomey's geocentric conception of the world, followed - around the year 1500 - by the heliocentric conception of the physician, theologian and astronomer Copernicus. Now, our expectations focus on Homo symbioticus as described by the researcher Joél de Rosnay who will develop an undreamtof perspective despite - or just because of - the enormous scientific progress.

Man's recollection of this intellectual capacities will cause him to view the world as a whole, i.e. to think and to act for the longer term and in a more perspective way than he used to do.

Bearing in mind that the half-life value of medical knowledge is getting increasingly shorter, we as physicians must avoid to be overwhelmed by the diagnostic and therapeutical possibilities and to neglect the human capital which primarily makes up our profession.

We have the enormous opportunity to contribute to the establishment of the new European health care system. The EU has the required financial resources if it is possible to make it clear to the population how important their health is.

The ERASMUS student exchange program, followed by the possibility to train assistant doctors in each EU country; the European specialist exam, the future common professional training; they are all standing for community and transfer of knowledge. Let us use these instruments that had unfortunately not yet been available to my generation.

We will overcome the challenges we are facing today if we develop long-term strategies connected with the recollection of our system of values as physicians. European ophthalmology must preserve its identity in the world with regard to research and practice.

\section{References}

European commissions Association Interantionale de la Mutualité European Social and Health Committee 


\section{Sažetak \\ OFTALMOLOGIJA U EUROPSKOJ UNIJI NA POČETKU 21. STOLJEĆA I NJENO OTVARANJE PREMA ISTOČNOJ EUROPI \\ R. Grewe}

U ovom članku je opisana trenutna situacija na Sveučilišnim klinikama, bolnicama i u privatnim ordinacijama u Europskoj uniji. Također su istaknute očekivane promjene koje će se dogoditi kao posljedica ulaska zemalja središnje Europe u europsku uniju. 